\title{
The European Union's Screening Framework for Foreign Direct Investment: Consequences for External Relations
}

\author{
Janina Witkowska \\ Ph.D., Full Professor at the University of Lodz, Faculty of Economics and Sociology \\ Department of World Economy and European Integration, Lodz, Poland \\ e-mail: janina.witkowska@uni.lodz.pl
}

\section{Abstract}

The Lisbon Treaty gives the European Union (EU) institutions new external competences, including foreign direct investment (FDI) in the common trade policy. Using these competences the European Commission formulated a proposal for a regulation establishing the screening framework for FDI, which entered into force in April 2019. The aim of this paper is to discuss the issue of FDI screening as an element of policies towards FDI applied by developed countries, to assess the justifications for its introduction, as well as the potential consequences of the screening framework for inflowing FDI into the EU. A need to protect the EU's strategic economic interests in relations with third countries was the reason for the introduction of the new tool at the EU level. The new system of screening FDI inflows into the EU is not centralized. The right to screen remains the sole responsibility of the Member States. The co-ordination mechanism at the level of the EU which has been constructed seems to give guarantees that common interests will be protected. The economic and political consequences of the EU's screening framework for FDI should be foreseen. Apart from administrative and compliance costs, as well as uncertainty and delays related to investment decision processes, two categories of potential consequences seem to be important. These are the expected reduced access to capital by some Member States, especially the 'new' ones, and the worsening of relations with external partners, especially China.

Keywords: Foreign direct investment (FDI), screening framework, the European Union, external relations, Chinese investment abroad

JEL: F21, F23, F42, K33 


\section{Introduction}

Although the Lisbon Treaty gives European Union (EU) institutions new external competences, including foreign direct investment (FDI), in the common trade policy, the final form and scope of the EU's common investment policy are still not established. The common EU investment policy has some problems that still need to be solved, i.e., investment protection issues, pre- and post-establishment guarantees, and the EU's international investment agreements that require the acceptance of both the EU and the Member States (so-called 'mixed agreements'). Apart from that, the EU institutions face a new task in this field, namely, the establishment of a mechanism protecting key strategic industries and assets in the EU while maintaining a conducive investment climate for attracting foreign investors. A screening framework for FDI should serve as a new instrument of the EU common investment policy, making it possible to achieve this aim.

The issue of FDI screening was discussed in the context of developing countries' policies towards foreign investors in the past. Nowadays, the necessity of screening is crucial for developed countries, as well. The openness of the EU towards foreign investment inflows from third countries, confirmed by various Treaties, might have some negative consequences for the economies of the Member States, their security, and public order. Hence, the EU's institutions have agreed that some regulations related to screening incoming FDI should be introduced.

The aims of this paper are to discuss the issue of FDI screening in the case of developed countries and to assess some justifications for its introduction as well as potential consequences of the newly agreed screening framework for inflowing FDI into the EU. The more detailed research tasks of the paper are as follows:

- to review hitherto approaches towards foreign direct investment screening under FDI policies of countries at different levels of economic development,

- to analyze the FDI screening framework as an element of the common investment policy of the EU,

- to discuss potential economic and political consequences of the implementation of the FDI screening framework in the EU,

- to assess the potential consequences of FDI screening for external investment relations, with special reference to EU-China relations.

The official information on the EU policy towards foreign investment and the FDI screening framework, as well as independent analyses, are used as references in the paper.

\section{Restrictions in recipient countries' policies towards foreign direct investment - A review}

Nowadays, capital movements in the form of FDI flows are treated as generally beneficial for recipient countries if certain conditions are fulfilled. However, there are always disputes about the potentially negative impact of FDI on the economic de- 
velopment of the host economies and their security and public order. Arguments for and against free FDI flows have given ground for the shaping of recipient countries' policies towards FDI. Important elements of these policies are some restrictions justified by market and institutional failures. The restrictions can be separated into two: those affecting market entry and post-entry operations. They include limitations on foreign ownership, management and operational restrictions, notification procedures, or screening (UNCTAD 2003, pp. 103-109; UNCTAD 2006, pp. 1-3). According to the definition applied in the new EU regulation, a screening mechanism means '... an instrument of general application, such as a law or regulation, and accompanying administrative requirements, implementing rules or guidelines, setting out the terms, conditions and procedures to asses, investigate, authorise, condition, prohibit or unwind foreign direct investments on grounds of security or public order' (Article 2, OJEU 2019).

The arguments for the pre-establishment restrictions of free FDI flows are as follows: Foreign investors, using their ownership-specific-advantages, could harm a host economy by reducing infant domestic entrepreneurship, by deterring local technological deepening, or by transferring and exploiting new technology outside of the recipient countries. Furthermore, foreign investors could also be less involved in spillovers than domestic firms and more prone to footloose activity. Finally, the presence of foreign firms in a domestic economy could lead to the loss of economic control by the recipient countries since foreign investors are responsive to signals from international markets and pressures from home country economies. The above-presented arguments for restricting FDI are believed to have merit, although the evidence of their practical significance is mixed (UNCTAD 2003, pp. 103-109).

Acceptance of the post-establishment restrictions towards FDI is based on the same theoretical thinking as in the case of the pre-establishment requirements. Market and institutional imperfections could be used here as arguments to deny foreign investors national treatment. Foreign investors may need to be restricted because of the infant enterprise arguments, i.e., that they have an advantage over local firms, which may lead to further segmentation of financial and labor markets. Their privileges, in the form of access to sensitive strategic information and technologies, possible dominant positions in recipient countries, and the danger of abusing their market power in the host countries are further arguments for introducing restrictions. In practice, the use of all these discriminatory instruments is combined with instruments that encourage foreign investors to make the best possible contribution to the economic development of host countries (UNCTAD 2003, p. 107).

Historically, restrictions and some requirements towards foreign investors were especially popular in developing countries. However, developed countries also used such instruments. Some strong fears related to the possibility of dependent development occurred in the case of some developing countries, which were clearly expressed by the so-called 'dependency school of thought.' It resulted in the creation of policies based on internal capital resources. 
During the 1980s, a growing number of developing countries turned towards outward-oriented economic policies of growth through exports and turned away from inward-looking import substitution policies. This change in the policies was triggered by a variety of factors. Among others, the need for hard currency to service the foreign debt of developing countries, accumulated in the early 1980s, was one of the reasons for the re-orientation of their policies (UNCTAD 1992, pp. 12-13). The attitude of these countries towards FDI started changing from being heavily regulatory and quite strict to more liberal. In the 1990s, foreign capital played an important role in the development strategies of many developing countries. Nevertheless, different types of restrictions towards FDI remained in their policies (UNCTAD 2006, pp. 1-3).

There were both political and economic reasons for the parallel liberalization of FDI inflows and the maintaining of FDI restrictions by developing countries. On the one hand, less developed countries could perceive restrictions towards foreign investment as instruments that guaranteed their independent political existence and economic development as well as a way to limit any potentially negative economic consequences of FDI inflows. On the other hand, the need for capital for their economic development led not only to the further opening of their economies towards foreign investors but also to offering them generous packages of incentives.

At the beginning of the 1990s, the trends towards liberalizing FDI flows occurred in economies in transition as well. These countries liberalized, privatized, and deregulated their economies, and liberal policies towards foreign investors were the immanent feature of these processes. Countries from Central and Eastern Europe (CEE), which were undergoing a systemic transformation, aspired to be members of international and regional organizations, such as the EU and the OECD. This resulted in liberal adjustments to the requirements imposed by these organizations.

As for policies towards FDI, the CEE countries used several restrictive instruments that allowed them to limit or control FDI inflows into some sensitive sectors of their economy at the beginning of the transformation. This was the subject of much controversy between the partners in the negotiations on the membership of these countries in the EU and the OECD. The governments of the transition countries were also under pressure from different social groups that expressed fears related to the potential dominance of foreign capital in their countries.

A discussion on the 'optimal' policy towards FDI led to the formulation of recommendations that tried to combine liberal concepts with elements of FDI screening/ monitoring. This was the case of Poland (Witkowska 2000; Pach 2001). The screening framework, by definition, gives an opportunity to check whether investment projects are suitable for the strategic aims of a recipient country. It also makes it possible to assess their particular impact on the economy. FDI screening seemed to be justified in Poland from the point of view of environmental protection, the assessment of the economic consequences of investment incentives offered to foreign investors, the impact of FDI projects on de-monopolization, and the competition processes at that time. 
The need to control FDI flows has also occurred in developed countries because of national security concerns in strategic sectors. For example, restrictions on foreign investment in the energy infrastructure of some developed countries are quite common practices nowadays. Countries such as Australia, Canada, the USA, and Japan have introduced legal rules, including screening regimes and ownership restrictions that allow them to limit the presence of foreign capital in key sectors for domestic economies, including energy (EC 2018, pp. 42-53). It is worth noting that countries such as China and Russia have adopted strict restrictions related to foreign investment in certain energy sectors as well. Recently, the problem of introducing the FDI screening framework has proved to be urgent for the EU as a whole (EC 2018a).

To sum up, two contradictory trends are observed in national investment policies, i.e., liberalization, promotion, and facilitation measures versus restrictions and regulations. The former constituted about 70\% of changes undertaken globally in 2018 (January-October), the latter 30\% (UNCTAD 2018, p. 2). The ratio of restrictions/regulations to the total policy measures was the highest since 2010. New measures oriented on creating more favorable investment conditions in industries such as retail trade, banking services, mining, and transportation were mainly adopted by developing and transition economies. The main motives behind the introduction of new restrictive or regulatory policy measures in developed countries were national security concerns about foreign ownership of critical infrastructures, core technologies, sensitive assets, or residential property. For example, the UK and the USA expanded the scope or conditions for the application of national security-related review mechanisms, Canada blocked an acquisition proposal for Aecon Group Inc. by a Chinese state-owned company due to national security concerns, while Norway and Hungary introduced a national security screening mechanism for foreign investment (UNCTAD 2018, pp. 1-4).

\section{The European Union's screening framework for foreign direct investment as an element of the common investment policy}

The EU is in the process of introducing a new tool of the common investment policy, i.e., a screening mechanism, to be used in co-operation with Member States (EC 2017; 2018a: 2019). The European institutions see it as necessary to protect public interests and secure the EU as a whole in the context of challenges related to the expansion of foreign investors in the EU's strategic sectors. The differentiated FDI screening mechanisms undertaken by the Member States thus far on the national security grounds, combined with the scrutiny of M\&A under the EU competition rules, are questioned as adequate regulatory tools to face these daunting new challenges (EPRS 2017, p. 1). 


\section{The hitherto legal basis for FDI screening at the EU level and some practices of the Member States}

Free capital movements constitute one of the basic freedoms in the EU, which is confirmed by Article 63 of the Treaty on the Functioning of the European Union (TFEU). The objective of this freedom is to ensure openness towards the other Member States and non-EU countries. However, this openness is not unconditional. Some restrictions might be introduced in specific situations which are foreseen by Article 65.1(b). These include infringements of national laws and regulations in the field of taxation, needs for the prudential supervision of financial institutions, and public policy or public security concerns (Consolidated Version of TFEU 2012). These provisions are treated as a derogation from the fundamental principle of free capital movements and payments, but they cannot be used as a means of arbitrary discrimination or a disguised restriction of this freedom. The exceptions from the free capital movement rule have been interpreted narrowly by the Court of Justice of the European Union (CJEU) in its case law (EPRS 2017, p. 5).

The Member States can evoke the above-mentioned Article 65(1)b as the legal basis for the protection of their essential interests on the grounds of public policy and public security. The restrictions can also be justified by the general interest, i.e., environmental protection, urban and country planning, and consumer protection, as recognized by the CJEU. However, they cannot be applied for purely economic reasons. Apart from the above-mentioned cases, the Member States can undertake any measures that they perceive as necessary for their security by using the Article 346(1) of the TFEU, which excludes the national defense sector from the application of the Treaty (EPRS 2017, p. 5).

At the EU level, the legal basis for FDI scrutiny constituted thus far two articles of the TFEU related to the EU competition rules, i.e., Articles 101 and 102. These provisions prohibit cartels and anti-competitive agreements as well as the abuse of a dominant position. The aim of mergers and acquisitions (M\&As) screening under these procedures is to ensure fair and undistorted competition on the internal market. However, the sources of funds used in M\&A transactions are not reviewed under the competition regulations (EPRS 2017, p. 5). Security or public order issues fall largely outside the scope of these regulations, with the exception of Article 21(4) of the 2004 EU Merger Regulation 139/2004 that allows for the protection of legitimate interests such as 'public security, plurality of the media and prudential rules' (EPRS 2019, pp. 2, 12).

Under national legal regulations, there was no single centralized FDI screening mechanism at the EU level that allowed for the preventive assessment of FDI made through M\&As by third-country investors. Under EU law, FDI screening was the exclusive responsibility of the EU Member States. Furthermore, no formal coordination was required among the Member States or between them and the European Commission (EPRS 2019, p. 2). 
As the practices of the EU Member States show, 14 countries have national FDI screening mechanisms in place that differ widely in scope and design (EP 2019). This can be illustrated by the example of investments in electricity and gas infrastructures relevant to the security of the supply. The Member States in question use screening law procedures in which the nationality of the investor plays an important role. In six of the procedures, the screening can be applied to non-EU investors, with the exception of investors from the EEA and EFTA countries. In two procedures, the review can be applied to all foreign investors, including those from the other EU Member States. The rest of the screening procedures embrace all investors, including national ones (EC 2018, Preamble). Other methods of controlling foreign investment in this field are ownership restrictions (18 Member States) and the usage of so-called Golden shares (3 Member States) (EC 2018, p. 13).

\section{Justifications for the introduction of the EU screening framework for foreign direct investment}

The general reasons for creating the new instrument of the EU's common investment policy, i.e., a framework for FDI screening, are related to (EC 2107a; EPRS 2017; Sunesen and Hansen 2018, p. 11; Gerhard 2018, pp. 815-817):

- long-term changes in shares of FDI stocks in the EU by foreign investors which originated in developed and emerging economies,

- changes in the sector distribution of FDI located in the EU, and the specific characteristics of the assets that are subject to the investment,

- entry modes preferred by investors from emerging economies,

- characteristics of foreign investors according to ownership and relations with states of their origin,

- lack of reciprocal access for EU firms to the Chinese market.

The statistical data show that the shares of FDI stocks in the EU by developed countries, such as the USA, Switzerland, and Japan, have been decreasing over the last two decades while the shares of other countries, such as Brazil, China, and Russia increased over the same period. The USA remains the largest investor in the EU, with a share of $41.5 \%$ in the EU FDI stock in 2015. However, this share decreased by about ten percentage points in comparison to 1995. A similar change is observed in the share of Switzerland in the EU FDI stocks. It decreased from 19.7\% in 1995 to $10.8 \%$ in 2015. It is worth noting that Japan's share in the EU FDI stocks fell from $7.7 \%$ to $2.9 \%$ in the same period. The shares in FDI stocks located in the EU by emerging economies are still not high in comparison with those by investors from developed countries. In the case of Brazil, China (including Hong Kong), and Russia, these shares increased from $0.3 \%, 0.2 \%$, and $0.4 \%$, respectively, in 1995 to $2.2 \%, 2 \%$, and $1.1 \%$ in 2015 . As a result of these processes, Brazil and China took fifth and sixth place on the list of the largest investors in the EU. Although non-EU investors control only $0.4 \%$ of EU companies, 
they account for about $13 \%$ of the total turnover, $11 \%$ of value-added, and $6 \%$ of the total employment in the EU (EC 2017b, pp. 3-4).

Since the end of the global financial crisis, changes in the sectoral distribution of FDI located in the EU have been observed. Foreign investors are increasingly interested in investing in the high-tech and manufacturing sectors in the EU, with special reference to strategic technologies, infrastructure, inputs, or sensitive information (EC 2017b, p. 6).

Furthermore, the increase in inward EU FDI flows continued to take the form of M\&As, while Greenfield projects were more than six times lower than all other types of FDI (EC 2017b, p. 5). The number of M\&A transactions by third-country investors in the EU amounted to 27,736 between 2003 and 2016. The UK, Germany, and France accounted for $60 \%$ of the total number of M\&As in that period. As for the sectoral distribution of M\&As, they increasingly take place in sensitive sectors of the EU economy (Sunesen and Hansen 2018, pp. 5-6).

A small portion of the M\&A transactions by third-country investors, i.e., 2\%, was completed by state-owned enterprises (SOEs). M\&As conducted by SOEs differ from the investment patterns of all non-EU investment. SOEs, although present in the economies of the UK, Germany, and France, invested more frequently in countries such as the Netherlands, Sweden, Italy, and Finland. They invested mainly in the utility sectors, natural resource extractions (electricity, gas, steam, and air conditioning; mining and quarrying), and transportation and storage. They invested less often in information and communication compared to private investors (Sunesen and Hansen 2018, p. 5).

Special attention is paid to Chinese FDI made in the EU in the form of M\&As, which amounted to $3 \%$ of the total number of M\&As by third-country investors (Sunesen and Hansen 2018, p. 5). The huge surge in Chinese acquisitions of EU companies, the considerable value of some of these transactions, as well as the sensitive/strategic sectors which were the target of these acquisitions, have aroused serious security concerns. In addition, the potential outflow of advanced technologies raised concerns about the future global competitiveness of the EU. The expansion of Chinese companies is perceived in terms of unfair competition since some of the transactions in question might be backed by Chinese state funding in pursuit of industrial policy (EPRS 2017, p. 4). Lack of reciprocity in the relations between the EU and China, as far as market access is concerned, provides the next argument for the introduction of screening mechanisms.

The idiosyncratic nature of Chinese FDI in the EU has also been pointed out (Knoerich, Miedtank 2018). The special characteristics of Chinese FDI in the EU distinguish them from other 'traditional' foreign direct investments. Apart from the above-presented characteristics of Chinese investment in the EU, some others are discussed, namely the fact that Chinese investors are latecomers with few firm-specific ownership advantages in the EU, some uncommon approaches that Chinese investors adopt when investing in Europe, and the controversial nature of some FDI projects (Knoerich, Miedtank 2018, pp. 7-8). 
To sum up, foreign investors might acquire control of or influence strategic sectors in the EU by using M\&As as the mode of entry into the EU market. In some cases, foreign investors owned or controlled by States of third countries could abuse their position through the acquired assets in order to damage the EU's interests. Such potential situations led to considerable public concerns about security and public order in the EU (EC 2017b, p. 6).

All the above-mentioned facts and phenomena could be treated as solid justification for the introduction of a common screening framework for FDI, especially in the context of relatively low FDI regulatory restrictiveness of the EU and its Member States in comparison with some third countries' regulations. However, the debate on political solutions related to the screening framework showed differentiated views and attitudes to this issue among the EU institutions, the EU Member States, and experts.

\section{The legislative procedure and the main features of the FDI screening framework at the level of the European Union}

The process of introducing the EU screening framework for FDI was initiated by a group of Members of the European Parliament (EP), who tabled a proposal for an EU act on the screening of foreign investment in strategic sectors of the EU, dated 24 March 2017 (EPRS 2019, p. 5). Then, three EU institutions were involved in the legislative procedure, aiming at the creation of such a framework. The first steps/stages in this process were (EPRS 2019, p. 5):

- the resolution of the European Parliament of 5 July 2017 on building an industrial strategy in which it called on the Commission and the Member States to screen third-country FDI in the EU's strategic industries, infrastructure, and key future technologies,

- two calls of the European Council (June, October 2017) to the Commission and the Council to deepen and take forward the debate on reciprocity in the fields of public procurement and investment,

- the initiative of the Commission of June 2017 to analyze investment from third countries in the EU's strategic sectors, while respecting the competences of the Member States in this area.

Thereafter, the proposal of the European Commission to create the EU screening framework for FDI was formulated in an official document published on 13 September 2017 (EC 2017c). This proposal was preceded by the Commission's reflection paper of 10 May 2017 on Harnessing Globalization, which recognized increasing concerns about foreign investors' acquisitions of European companies with key technologies (EC 2017). The EC President, Jean-Claude Juncker, clearly presented the position of the EU in his annual State of the Union address of 2017 in the context of the observed trends: 'Let me say once and for all: we are not naïve traders. Europe must always defend its strategic interests. This is why today we are proposing a new EU framework for investment screening' (EC 2017). 
Then, talks with the two co-legislators, i.e., the European Parliament and Council, started in mid-2018, and at the end of the same year, the agreement was reached on the screening of FDI for the EU's security (EP 2018). In a vote on 14 February 2019 (EP 2019), the European Parliament accepted the setting up of an EU-level tool to screen FDI on the grounds of security to protect strategic sectors. The Council of the EU approved a framework for the screening of foreign direct investments into the Union on 5 March 2019 and this was the final stage of the legislative process (EC 2019). Regulation (EU) 2019/452 of 19 March 2019 was published in the Official Journal of the European Union and the new law entered into force in April 2019 (OJEU 2019).

According to the accepted regulation, the FDI screening framework in the EU consists of two components, i.e., the newly created mechanism at the level of the EU and screening mechanisms used by the Member States. The regulation creates a cooperation mechanism involving both the Commission and the Member States, which should enable them to exchange information and raise concerns related to specific investment projects. This seems to be the essence of the new regulatory solution.

The Member States may maintain, amend, or adopt mechanisms to screen foreign direct investments in their territory on the grounds of security or public order (Article 3.1 OJEU 2019). Hence, the regulation does not limit the Member States' right to set up a screening mechanism or to screen particular foreign direct investment projects, which are treated as the sole responsibility of the Member States. At the same time, the regulation does not require Member States which do not screen FDI to introduce any investment screening mechanisms.

However, some key requirements towards the national screening mechanisms have been formulated in the regulation. These are the transparency of rules and procedures, non-discrimination among investors, the confidentiality of information exchanged, the possibility of recourse against screening decisions of the national authorities, and undertaking measures to identify and prevent the circumvention of the screening mechanisms and screening decisions (Article 3.2 OJEU 2019).

The criteria for determining whether FDI is likely to affect security or public order are defined in the form of an indicative list in the regulation (Article 4 OJEU 2019). The Commission and Member States may take into consideration the potential effects of FDI on:

- critical infrastructure defined in a broad sense; it includes both physical and virtual infrastructure, i.e., energy, transport, water, health, communications, media, data processing or storage, aerospace, defense, electoral or financial infrastructure, and sensitive facilities, as well as land and real estate crucial for the use of this infrastructure,

- critical technologies and dual-use items, including, among others, artificial intelligence robotics, semiconductors, cyber-security, quantum and nuclear technologies, and nanotechnologies,

- the supply of critical inputs, including energy or raw materials, as well as food security, 
- access to sensitive information, including personal data,

- the freedom and plurality of the media.

In addition, the Commission and Member States may consider other sensitive aspects of the planned FDI project. These could be the direct or indirect control of a foreign investor by the government of a third country, the previous involvement of a foreign investor in activities affecting security or public order in a host country, as well as the risks that a foreign investor engages in illegal or criminal activities.

The regulation also lists projects and programs of Union interest that could be affected by FDI on the grounds of security or public order and which deserve special attention from the Commission. These are the projects and programs which involve a substantial amount or a significant share of Union funding, or which are covered by Union law regarding critical infrastructure, critical technologies, or critical inputs and which are essential for security or public order. The list includes European GNSS programs (Galileo \& EGNOS), Copernicus, Horizon 2020, Trans-European Networks for Transport (TENT-T), Trans-European Networks for Energy (TEN-E), Trans-European Networks for Telecommunications, European Defence Industrial Development Programme, and Permanent structured cooperation (PESCO) (Annex OJEU 2019).

The regulation foresees the establishment of two tracks of the cooperation mechanism between the Commission and the Member States, i.e., in relation to FDI undergoing and not undergoing screening (Articles 6 and 7 OJEU 2019). The obligations and entitlements of the parties included in these mechanisms are defined by the regulation as well as the timeframe of the procedure.

The first stage of the cooperation process concerning FDI undergoing screening starts when a Member State, where the FDI takes place, notifies both the Commission and other Member States of cases which are undergoing national screening. The Member State in question is obliged to provide information (Article 9 OJEU 2019) on the investment, which includes basic data on the FDI, i.e., the ownership structure of the foreign investor and of the undertaking in which the FDI is planned or has been completed, the approximate value of the FDI project and sources of the funding of the investment, sectors in which the foreign investors operate and in which the undertaking is planned or has been completed, the Member States in which the foreign investor and the undertaking in question conduct relevant business operations, as well as the date when the FDI is planned to be completed or was completed.

Furthermore, the Member State may request that the Commission issues an opinion or that other Member States provide comments when it duly considers that an FDI in its territory is likely to affect its security or public order.

At the second stage of the cooperation process, both the other Member States and the Commission can request additional information from the Member State initiating the screening. The Member States may provide comments, and the Commission may issue an opinion addressed to the Member State undertaking the screening. This opinion is issued when the Commission considers that the FDI undergoing screening is likely to affect security or public order in more than one Member State, or has rele- 
vant information concerning that FDI project. The Commission may issue an opinion, following comments from other Member States or irrespective of whether they provided comments. However, the Commission shall issue such an opinion where justified, after at least one-third of Member States consider that the FDI is likely to affect their security or public order.

In addition, the regulation stipulates that the Commission may issue an opinion addressed to the Member States where FDI is planned or has been completed if it is likely to affect projects or programs of Union interest mentioned above.

The third stage embraces actions undertaken by the Member State initiating the screening of the FDI. Namely, the Member State shall give due consideration to the comments of other Member States and to the opinion of the Commission. If the Member State does not follow the EU's opinion, it should provide an explanation, in line with its duty of sincere cooperation under Article 4(3) TFEU. The final screening decision belongs to the Member States undertaking the screening, however. The whole procedure under the cooperation mechanism concerning an FDI undergoing screening usually lasts 35 days.

The cooperation process regarding an FDI not undergoing screening is similar to that described above. It foresees other Member States providing comments to a country in which an FDI is planned or completed if they consider that this investment is likely to affect its security or public order, or if they have relevant information to that investment. The Commission may issue a non-binding opinion following comments from other Member States, or it shall issue such an opinion where justified after at least one-third of Member States consider that FDI is likely to affect their security or public order. The difference between the two tracks can be attributed to the timeframe, which is up to 15 months after the completion of the investment.

\section{The potential consequences of the EU framework for FDI screening}

The proposal to introduce the new EU tool provoked differentiated opinions and controversy during the obligatory consultations. The opinions varied from accepting the regulation's proposal, including the entitlement of the Commission to screen an FDI (e.g., the opinion of the EESC), to opposing views expressed by some academics (EPRS 2019, pp. 7-9). Some proposals were unacceptable for the stakeholders, especially those authorizing the Commission to play a decisive role in screening processes.

There might be potential consequences of the new EU regulation for the EU as a whole, its Member States, and third countries. In addition, they might be intertwined and bring mirror effects.

The first assessments, taking into account the different scenarios of sensitive sectors being scrutinized, show potential implications related to: '...1) the administrative resources required to conduct the screening, 2) the compliance costs, uncertainty and 
delays experienced by the acquiring firm, and 3) FDI inflows and access to capital for domestic firms' (Sunesen and Hansen 2018, p. 42).

The administrative costs are caused by the need to identify cases, the number of files, the complexity of the screening procedure, as well as the willingness of the potential investor to cooperate and disclose the required information. It is estimated that the number of files at the level of the EU might increase 1.5-2.5 times in comparison to the pre-regulation period. The administrative costs include personnel costs as well as the costs of experts, which constitutes a financial burden for the EU and its Member States. The practice of some of the Member States thus far shows that the cost of screening can be borne by an applicant or a notifying party (Sunesen and Hansen 2018, p. 42).

Compliance costs, uncertainty, and delays may occur in the process of screening. These costs, which are connected with foreign investors adjusting to EU requirements, or delays in investment projects, will be borne by the firms applying. If it is the case, these costs could negatively influence their long-term competitiveness. This causes a potential burden for foreign investors. The cooperation mechanism between the Commission and the Member States is expected to extend the decision period. As the final decision might be negative, it gives rise to uncertainty on the investor's side. The occurrence of the above-mentioned costs might negatively influence potential investors' decisions on investing in the EU Member States. This could result in some Member States having reduced access to capital, especially the smaller and 'new' ones (Sunesen and Hansen 2018, pp. 43-44).

The last aspect requires special attention because the Member States show differentiated attitudes towards third countries' investment, especially Chinese investment. The new EU Member States from CEE and China seem to be interested in cooperation under the 'One Belt, One Road' (OBOR) initiative, which was not explicitly approved by the 'old' Member States. The new EU Member States experience a shortage of capital for infrastructure projects. The economic interests of the 'old' Member States are related to protecting strategic sectors and key technologies in the context of security and public order. In turn, the new EU framework might be perceived by these new Member States as an effective instrument of controlling FDI inflows from other third countries, e.g., Russia. These discrepancies in economic and political interests could lead to tensions within the EU.

Furthermore, the new EU screening mechanism could be perceived by investors from third countries as discriminatory and disproportionate, and it could trigger a negative reaction in third countries (Sunesen and Hansen, 2018, pp. 43-44). The new regulation does not officially target Chinese investment flows into the $\mathrm{EU}$, and the Chinese authorities do not react officially against it. However, it is believed that Chinese FDI in the EU is a major reason for the legislation. Some fears are expressed that: '...Chinese FDI coming into the EU might be subject to disproportionate scrutiny, even discrimination in the coming years' (Weihua 2019). In this context, there is an opinion that the EU, as a whole integration grouping, will be less open to FDI while Chi- 
na further opens up its economy (Weihua 2019). China has adopted the new Foreign Investment Law, which will enter into force on 1 January 2020. It includes provisions addressing issues of crucial importance for foreign investors, i.e., pre-establishment national treatment, the protection of foreign investors' intellectual property rights, and improved investment protection in comparison to the previous law (China adopted the Foreign Investment Law 2019).

The analyses and assessments confirm that the new EU screening mechanism could particularly impact Chinese investors since the criteria formulated in the regulation encourage the Member States to specifically screen state-supported investment projects in sensitive technologies and critical infrastructure. According to estimations of the Rhodium Group and the Mercator Institute for China Studies, $82-83 \%$ of Chinese M\&A transactions in Europe in 2018 would fall under at least one of those criteria (Hanemann, Huotari, Kratz 2019, pp. 7, 18). Although the impact of the new regulation on Chinese investment might not automatically be negative, the strengthening of the screening mechanism in the Member States has already impacted Chinese investment in the EU. The Chinese FDI inflows into the EU continued to decline in 2018, which could be attributed to the stricter control and screening carried out by the Member States on the basis of hitherto national mechanisms. Meanwhile, transactions worth 15 billion EUR were pending at the beginning of 2019 (Hanemann, Huotari, Kratz 2019, pp. 7, 18, 20). It has also been noticed that the introduction of the EU screening framework could cause a short-term decrease in Chinese investors' activities because they might be checking the effectiveness of the new system (Szczudlik, Wnukowski 2019 , p. 2). As these analyses show, the new regulation is bound to influence economic and even political relations between the EU and third countries.

The debate on risks from economic engagement with China is expected to extend far beyond FDI screening, and the broader scrutiny of Chinese commercial presence in Europe might happen in the future (Hanemann, Huotari, Kratz 2019, pp. 7, 20-21).

Finally, the impact of the new EU framework for FDI should be discussed in the context of the development of the EU's common investment policy. Although some doubt has been raised about whether the new EU screening system can be treated as a solution or a problem (Esplugues 2019), regulation in this field might be perceived as the first step in achieving progress in establishing a new instrument of the EU's common investment policy. Some provisions of the new regulation confirm that the EU's common interests in this field have to be taken into account. They are the provisions related to the cooperation mechanisms between the Member States and the EC, including the obligatory exchange of information between parties, the obligation to explain why EC opinions are not taken into account, and the establishment by all the Member States and the EC of contact points for the implementation of the regulation. 


\section{Conclusions}

Two contradictory trends have occurred in national investment policies over time, i.e., liberalization, promotion, and facilitation measures versus restrictions and regulations on FDI.

The change in perception of FDI restrictions has been observed in the longer term. The screening mechanism was treated as an instrument of restrictive policy towards FDI in developing countries and economies in transition two to three decades ago. Nowadays, developed countries introduce this instrument as a fully justified component of their policies towards FDI in their strategic sectors. In general, FDI screening might be perceived as a soft instrument substituting more restrictive policy instruments, such as 'negative lists.'

The EU common investment policy, established by the Lisbon Treaty, gives EU institutions new external competences including foreign direct investment (FDI) into the common trade policy, and it confirms the delimitation of competences between the Union and the Member States. This legal basis was used for the establishment of the EU screening framework for FDI. The justification for the introduction of the new tool was the need to protect the EU's economic interests in relations with third countries.

The new system of screening FDI inflows into the EU from third countries is not centralized. The right to screen remains the sole responsibility of the Member States; hence, their hitherto competences are not limited. This feature of the new system is criticized by the proponents of the leading role of the EU institutions in this area. However, the co-ordination mechanism which has been constructed at the level of the EU seems to give guarantees that common interests will be protected.

The consequences of the EU screening framework for FDI might have economic and political dimensions. Apart from administrative and compliance costs, as well as uncertainty and delays related to investment decision processes, two categories of potential consequences seem to be important: the expected reduced access to capital by some Member States and the worsening of the relations with external partners, especially China.

All potential consequences of the FDI screening framework, foreseen for the whole EU, may occur in the case of the new EU Member States from Central and Eastern Europe. Additional costs, uncertainty, and delays connected with screening processes may negatively influence the scale of FDI inflows into their economies. The EU screening framework for FDI may also have adverse effects on future cooperation between the new EU Member States and China in the field of infrastructure projects as well as some activities in other sectors. Nevertheless, the new EU Member States from Central and Eastern Europe may be interested in using the new instrument to control FDI inflows from the third countries, e.g., from Russia.

Dilemmas arise regarding whether the new regulation constitutes a solution or a problem, and whether it will be used to discriminate against foreign investors. 
The effectiveness of the new EU mechanism will be checked in practice. The achievement of the main EU goals related to the protection of public interests and security might encounter official or unofficial counter-measures undertaken by third-country partners.

\section{References}

Consolidated Version of the Treaty on Functioning of the European Union (2012), Official Journal of the European Union, C326/47 (accessed: 26.10.2012).

EC (2017), State of the Union 2017 - Trade Package: European Commission proposes framework for screening of foreign direct investments, The European Commission, Brussels, 14 September 2017, http://trade.ec.europa.eu/doclib/press/index.cfm?id=1716 (accessed: 11.01.2019).

EC (2017a), Foreign Direct Investment-An EU Screening Framework, State of the Union 2017, The European Commission, Brussels.

EC (2017b), Commission Staff Working Document Accompanying the document Proposal for Regulation of the European Parliament and of the Council establishing a framework for screening of foreign direct investments into the European Union, COM (2017) 487 final, Brussels SWD (2017) 297 final.

EC (2017c), Proposal for a Regulation of the European Parliament and of the Council establishing a framework for screening of foreign direct investments into the Europen Union, COM (2017) 487 final (accessed: 13.09.2017).

EC (2018), Review of national rules for the protection of infrastructure relevant for security of supply, Final Report, The European Commission, Brussels, February 2018.

EC (2018a), Commission welcomes agreement on foreign investment screening framework, Press release, The European Commission, Brussels, 20 November 2018, http:// europa.eu/rapid/press-release_IP-18-6467_en.htm (accessed: 11.01.2019).

EC (2019), Foreign Investment Screening: new European framework to enter into force in April 2019, Brussels, 5.03.2019, http://europa.eu/rapid/press-release_IP-19-1532_ en.htm (accessed: 4.04.2019).

EP (2018), Agreement reached on screening of foreign direct investment for EU security, Press releases, Brussels 20.11.2018, http://www.europarl.europa.eu/news/en/pressroom/20181120IPR19506/agreement-r (accessed: 11.01.2019).

EP (2019), EU to scrutinize foreign direct investment more closely, Press Releases, Plenary Session, “News. European Parliament” (accessed: 14.02.2019).

EPRS (2017), European Parliamentary Research Service, Foreign direct investment screening. A debate in light of China - EU FDI flows, Briefing, May 2017.

EPRS (2019), European Parliamentary Research Service, EU framework for FDI screening, Briefing, February 2019.

Esplugues, C. (2019), A future FDI screening system: solution or problem?, "Columbia FDI Perspectives” No. 245, February 11, 2019.

Gerhard, M. (2018), Mehr Schutz vor auslandischen Direktinvestitionen?, "Wirtschaftsdiens", No. 11. https://doi.org/10.1007/s10273-018-2371-y 
Hanemann, T., Huotari, M., Kratz, A. (2019), Chinese FDI in Europe: 2018 Trends and Impact of New Screening Policies, A Report by Rhodium Group (RHG) and the Mercator Institute for China Studies (MERICS), March 2019.

Knoerich, J., Miedtank, T. (2018), Chinese Foreign Direct Investment in the EU, "CESifo Forum" Vol. 19, No. 4, December.

OJEU (2019), Regulation (EU) 2019/452 of the European Parliament and the Council of 19 March 2019 establishing a framework for the screening of foreign direct investments into the Union, Official Journal of the European Union L 79 I, 21.03.2019.

Pach, J. (2001), Bezpośrednie inwestycje zagraniczne $w$ świetle bezpieczeństwa ekonomicznego na przykładzie Polski w latach dziewięćdziesiątych XX wieku, Wydawnictwo Naukowe Akademii Pedagogicznej im. Komisji Edukacji Narodowej, Prace Monograficzne, No. 309, Kraków 2001.

Sunesen, E.R., Hansen, M.M. (2018), Screening of FDI towards the EU, Copenhagen Economics, Danish Business Authority.

Szczudlik, J., Wnukowski, D. (2019), Reforma mechanizmów kontroli inwestycji w USA i UE: odpowiedź na aktywność Chin, "Biuletyn”, PISM - Polski Instytut Spraw Międzynarodowych, No. 1 (1749), 2 stycznia 2019.

UNCTAD (1992), Formulation and Implementation of Foreign Investment Policies, UN, New York.

UNCTAD (2003), World Investment Report. FDI Policies for Development: National and International Perspectives, UN, New York, and Geneva.

UNCTAD (2006), Measuring Restrictions on FDI in Services in Developing Countries and Transition Economies, UN, New York, and Geneva.

UNCTAD (2018), Investment Policy Monitor, December, Issue 20.

UNCTAD (2019), China Adopted the Foreign Investment Law, March 15, 2019, Investment Policy Monitor, https://investmentpolicy.unctad.org/investment-policy-monitor/measures/3375/china-china-adopted-the-foreign-investment-law (accessed: 20.06.2019).

Weihua, Ch. (2019), EU's new FDI screening should not target China, "China Daily", 8 March.

Witkowska, J. (2000), Polityka wobec bezpośrednich inwestycji zagranicznych, [in:] Skutki napływu zagranicznych inwestycji bezpośrednich (Materiał z posiedzenia Rady Społeczno-Gospodarczej), Warszawa. 


\title{
Streszczenie
}

\section{Screening bezpośrednich inwestycji zagranicznych w Unii Europejskiej: konsekwencje dla stosunków zewnętrznych}

\begin{abstract}
Traktat Lizboński nadał instytucjom Unii Europejskiej (UE) nowe kompetencje w stosunkach zewnętrznych, włączając bezpośrednie inwestycje zagraniczne (BIZ) do wspólnej polityki handlowej. Wykorzystując te kompetencje Komisja Europejska sformułowała propozycję regulacji ustanawiającej ramy dla screeningu BIZ, która weszła w życie w kwietniu 2019 r. Celem niniejszego artykułu jest dyskusja nad kwestią screeningu jako elementu polityki wobec inwestorów zagranicznych, prowadzonej przez kraje rozwinięte, ocena uzasadnienia wprowadzenia screeningu oraz jego potencjalnych konsekwencji dla napływu BIZ do UE. Przyczyną wprowadzenia nowego instrumentu na poziomie UE była potrzeba ochrony strategicznych ekonomicznych interesów UE w stosunkach z krajami trzecimi. Nowy system screeningu BIZ napływających do UE nie jest scentralizowany. Prawo do screeningu pozostaje w wyłącznej kompetencji krajów członkowskich. Jednak mechanizm koordynacji na szczeblu UE wydaje się dawać gwarancję, że wspólne interesy będą chronione. Należy spodziewać się, że nowa regulacja przyniesie ekonomiczne i polityczne konsekwencje. Oprócz kosztów administracyjnych, a także związanych z procesami dostosowawczymi, niepewnością i opóźnieniami projektów inwestycyjnych, dwie kategorie skutków wydają się być szczególnie istotne. Są to: ograniczenia w napływie BIZ do niektórych krajów członkowskich UE, w szczególności tzw. 'nowych' oraz pogorszenie się relacji z krajami trzecimi, w szczególności z Chinami.
\end{abstract}

Słowa kluczowe: Bezpośrednie inwestycje zagraniczne (BIZ), screening, Unia Europejska (EU), stosunki zewnętrzne, chińskie inwestycje zagraniczne 